\title{
SATISFACTION LEVEL OF DEGREE STUDENTS ON E-LEARNING DURING COVID-19 SITUATION (A COMPARATIVE STUDY OF RURAL AND URBAN AREA IN BHADRADRI KOTHAGUDEM DISTRICT)
}

\author{
Parelli Sreenivas $1 \bowtie(D$
}

${ }^{1}$ Lecturer in Commerce, Government Degree College, Paloncha, Bhadradri District, Telangana State, India.

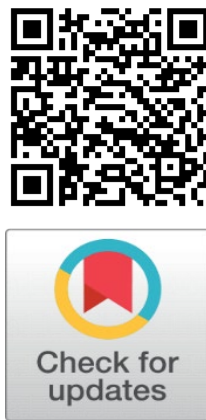

Received 17 October 2021

Accepted 17 November 2021

Published 30 November 2021

\section{CorrespondingAuthor}

Parelli Sreenivas,

sreeenivasparelli@gmail.com

DOI

10.29121/granthaalayah.v9.i11.2021 .4363

Funding: This research received no specific grant from any funding agency in the public, commercial, or not-for-profit sectors.

Copyright: (C) 2021 The Author(s). This is an open access article distributed under the terms of the Creative Commons Attribution License, which permits unrestricted use, distribution, and reproduction in any medium, provided the original author and source are credited.

\section{ABSTRACT}

In December 2019, Wuhan, China, experienced an unidentified viral pandemic of pneumonia. The World Health Organization (WHO) declared the finding of a new corona virus, SARS-Cov-2, on January 9, 2020. In the Covid-19 pandemic situation education sector has faced enormous provocations. More than 200 countries across the world have been distressed with the covid-19. Conforming to UNESCO, above 32 crore Indian students have been concerned by the covid-19 led lockdown. Following the shake of Covid-19, HonorablePrime Minister of India Sri.Narendra Modi declared a lockdown beginning on March 25, 2020 and lasting until May 31, 2020. This lockdown has severely disrupted India's education sector, forcing students and faculty to remain at home and continue their education online.

The Commissioner of Collegiate Education in Telangana State formally began Online Classes during the Lockdown period. The present paper is an attempt to a comparative study and analyzes the Satisfaction level of Degree students on online classes during covid 19 situation of Rural and Urban area in Bhadradri Kothagudem district, Telangana State. It also aims to investigate the students' opinions and issues encountered during online classes. The Online survey was carried out with the help of Google Form send to students through e-mail and WhatsApp and collected responses from about 140 Degree students of Government and Private colleges in Bhadradri district, Telangana State. It demonstrates that the majority of students attending to online classes using smart phones with Android operating systems. For e-learning, the majority of students have used the Zoom online platform. Students have experienced a variety of issues, including Live streaming and Audio disruptions, insufficient data, power outages, lack of clarity in lectures, missing face-to-face connection, and a general lack of enthusiasm. During this Covid-19 circumstance, students from rural areas have had a difficult time accessing online lectures and study materials.

Keywords: Online Classes, Covid-19, Degree Students, Satisfaction Level

\section{INTRODUCTION}

The Covid-19 pandemic has spread across the globe, affecting practically all countries and territories. In December 2019, Wuhan, China, experienced an unidentified viral pandemic of pneumonia. The World Health Organization (WHO) declared the finding of a new corona virus, SARS-Cov-2, on January 9, 2020. In Covid-19 pandemic situation education sector has faced enormous provocations. More than 200 countries across the world have been distressed with the covid-19. Conforming to UNESCO, above 32 crore Indian students have been concerned by the covid-19 led lockdown. This lockdown has severely disrupted India's education sector, forcing students and faculty to remain at 
home and continue their education online. The education industry has not been immune to the pandemic's effects. On January 30, 2020, the first Covid-19 positive cases in India were reported in Kerala. Following the shake of Covid-19, Honorable Prime Minister of India Sri.Narendra Modi declared a lockdown beginning on March 25, 2020 and lasting until May 31, 2020.

To turn these Covid-19 pandemic situation Educational Institutions have turned into opportunities for learning, the Ministry of Human Resource Development initiated a host of measures to continue their education. Higher education institutions across the country have begun offering online classes as part of these initiatives. Commissioner of Collegiate Education (CCE), of Telangana State, has been followed the Instructions given by MHRD, and started online classes for Degree students. Degree College Lecturer has adapted to new method and conducted online classes. In this survey in Bhadradri Kothagudem district, above $55 \%$ of the students have attended online classes with the help of various online platforms, such as Zoom, Google Meet, YouTube etc. About $45 \%$ of the students are from Rural area background, they unable to attend the online classes due to various reasons such as lack of android phones, insufficient data, poor internet facility, power outages and technical glitches etc.

\section{REVIEW OF LITERATURE}

In this field, few studies were conducted in India. The researcher reviewed many researchers conducted in India and abroad to find out the correct area to carry out the research work, which will be fruitful for the professionals and country.

Jindal and Chahal (2018) have made an Online education have the potential to transform the educational landscape if it is implemented in collaboration with industry, universities, and the government. To bridge the gap, drastic changes in course curriculum are required. Students must be industry ready after graduating. The educational process must be changed to make it more practical through the use of technology. In addition, courses should be designed in a variety of languages to broaden their reach and provide more opportunities for rural youth in India. Designing methods to improve the social skills of online learners necessitates creativity.

Tari and Amonkar (2020) in their research, technology has become a necessity in today's world. It's difficult to envision higher education without the usage of digital tools, which have supplied a wealth of educational and academic knowledge. It's also important to remember that it shouldn't promote power and inequality patterns. It should not create a digital divide between the wealthy and the less fortunate. Due to India's diverse socioeconomic situations, we cannot anticipate all essential resources to be available in a country like India

Neelavathy (2020) in her study the lockdown amidst COVID-19 has made significant disruptions in academic activities. Her present study assessed the learning status of undergraduate and postgraduate students during this pandemic. Although a substantial proportion of students are using digital platforms for learning, many of them face huge challenges in online study. The study has suggested the following recommendations to the government, policymakers and institutional authorities. There should be made a uniform academic plan for the universities and colleges and initiate a proper education continuity plan to continue the learning process during this pandemic

Kantipudia et al. (2021) in their article depicts the status of Covid -19 around the world, with a focus on India. Also shown are the difficulties faced by young graduates and students in the higher education sector as a result of the ongoing 
lockdown of educational institutions and the widespread spread of corona virus. Based on the detailed study, it identifies the various opportunities to continue the teaching learning process, particularly by using open-source learning management system, which is commonly used by various universities and colleges to carry out tutorial and evaluation purposes. However, in India, due to a lack of computers and internet access, particularly among village residents.

Siddiqui et al. (2021) in their study revealed that, Gender, urban/rural location, and spatial distance all had an impact on the anxiety, fear, sadness, anger, and coping strategies of nurses and nursing students. Nurses have stronger emotional responses and are more willing to use problem-solving coping strategies than nursing students. This study delves deeper into the connection between emotional responses and coping strategies. There could be a "more coping-more panic" cycle among nurses, but not necessarily among nursing students.

\section{STATEMENT OF THE PROBLEM}

Bhadradri Kothagudem district, a newly emerged district of the infant state Telangana, is a symbol of diversity as it is one of the highly industrialized areas in the state and similarly with the tribal population. Most of the mandals of the district are dominated by the backward tribal population and a few areas are covered with basic industries like coal extraction, thermal power production, paper production, etc., Well-educated employees on one side, agency illiteracy on the other side show the extremes of this region. The present study is an attempt to study and analyze the Satisfaction level of Degree students on online classes during covid-19 situation. It also aims to investigate the students' opinions and issues encountered during online classes.

\section{OBJECTIVES OF THE STUDY}

1) To know the satisfaction level of the students during online classes.

2) To determine the Degree students' knowledge about online Platforms.

3) To study which section of Students (i.e., Gender, age, Stream of study, urban and rural area, etc.,), are inkling towards online classes.

4) To investigate the students' opinions and issues encountered during online classes.

\section{METHODOLOGY OF STUDY}

\section{1) Data collection}

To undertake this study the data collected from two sources

- Primary source: The Online survey was carried out with the help of Google form through e-mail and WhatsApp across Bhadradri Kothagudem district.

- Secondary Source: Data for this study has been collected from various sources such as Journals, books, magazines and articles.

2) Sample size A sample of 140 students from various degree colleges of varying age, gender, stream of study and area of residence were chosen to understand their Satisfaction level towards online classes.

Sampling method: There are 24 mandals and 2 revenue divisions in Bhadradri district. In Kothagudem revenue division there are 15 mandals and in Bhadrachalam revenue division there are 9 mandals. Total 24 mandals have been selected in the 
systematic sampling method. From these mandals 140-degree college students have been selected in a simple random sampling method.

3) Statistical Tools Used: The Data is analyzed with SPSS (version. 28) software was used for the analysis. The study utilized descriptive statistics such as mean and standard deviation. The mean was used to measure the Satisfaction level of students during online classes in rural and urban areas. The Chi-square test was used to test for the student's final opinion towards e-learning during covid-19 situations.

\section{DATA ANALYSIS AND INTERPRETATION}

\section{Demographic profile of the students}

This section contains demographic information of the respondents in the study area. It is concerned with Gender, Age, Stream of study and area of the residence.

\begin{tabular}{|ccccccc}
\hline \multicolumn{6}{c}{ Table $\mathbf{1}$ Gender-wise distribution of the respondents } \\
\hline Sex & Rural & Percentage & Urban & Percentage & Total & Percentage \\
\hline Male & 44 & $56 \%$ & 37 & $60 \%$ & 81 & $58 \%$ \\
\hline Female & 34 & $44 \%$ & 25 & $40 \%$ & 59 & $42 \%$ \\
\hline Total & 78 & 100 & 62 & 100 & 140 & 100 \\
\hline
\end{tabular}

Source: Primary data

The above table reveals that from rural areas 56 percent are male and 44 percent are female and from the urban area 60 percent are male and 40 percent are female. The majority of the respondents are male students from rural and urban are actively participated in the online classes.

\begin{tabular}{|c|c|c|c|c|c|c|}
\hline Age & Rural & Percentage & Urban & Percentage & Total & Percentage \\
\hline Below 17 years & 8 & $10 \%$ & 13 & $21 \%$ & 21 & $15 \%$ \\
\hline 17-19 & 20 & $26 \%$ & 20 & $32 \%$ & 40 & $29 \%$ \\
\hline Above 19 years & 50 & $64 \%$ & 29 & $47 \%$ & 79 & $56 \%$ \\
\hline Total & 78 & 100 & 62 & 100 & 140 & 100 \\
\hline
\end{tabular}

The above table shows that the majority of the students (64\%) are from a rural area in the age group above 19 years and the remaining (36\%) of the students are in the age group of 17-19 and below 17 years. From the urban area, the majority of the students (47\%) are in the age group of above 19 years and the rest (53\%) of the students are in the age group of 17-19 and below 17 years. This study indicates that most of the students are in age above 19 years are actively participating in online classes. 


\begin{tabular}{|cccccccc}
\hline \multicolumn{2}{|c|}{ Table 3 Stream of study of the respondents } & & & \\
\hline Stream of study & Rural & Percentage & Urban & Percentage & Total & Percentage \\
\hline Commerce & 32 & $41 \%$ & 33 & $53 \%$ & 65 & $46 \%$ \\
\hline Science & 21 & $27 \%$ & 17 & $27 \%$ & 38 & $27 \%$ \\
\hline Arts & 25 & $32 \%$ & 12 & $20 \%$ & 37 & $27 \%$ \\
\hline Total & 78 & 100 & 62 & 100 & 140 & 100 \\
\hline
\end{tabular}

Source: Primary data

The above table depicts that from the rural area, the majority (41\%) of the students are from the Commerce stream and the rest (49\%) of the respondents are from Science and Arts streams. From the urban area, 53 percent of the students are Commerce and the remaining (47\%) are from Science and Arts stream. This study reveals that the majority of the students are Commerce stream and strongly participated in the online classes.

Students E-learning during Pandemic Situation analyzed in the tables from 4 to 9.

\begin{tabular}{|c|c|c|c|c|c|c|}
\hline Particulars & Rural & Percentage & Urban & Percentage & Total & Percentage \\
\hline Yes & 44 & $56 \%$ & 30 & $48 \%$ & 82 & $59 \%$ \\
\hline No & 34 & $44 \%$ & 32 & $52 \%$ & 58 & $41 \%$ \\
\hline Total & 78 & 100 & 62 & 100 & 140 & 100 \\
\hline
\end{tabular}

Source: Primary data

The Table 4 shows that from the rural area, the majority (56\%) of the students are aware of e-learning before the pandemic and 48 percent of urban area students are used e-learning before the pandemic.

\begin{tabular}{|cccccccc}
\hline \multicolumn{5}{|c|}{ Table 5 Were you familiar with the Swayam e-learning programme? } \\
\hline Particulars & Rural & Percentage & Urban & Percentage & Total & Percentage \\
\hline Yes & 40 & $51 \%$ & 37 & $60 \%$ & 100 & $71 \%$ \\
\hline No & 38 & $49 \%$ & 25 & $40 \%$ & 40 & $29 \%$ \\
\hline Total & 78 & 100 & 62 & 100 & 140 & 100 \\
\hline
\end{tabular}

Source: Primary data

The above table inferred that 51 percent of rural area students are familiar with the Swayam e-learning program, and 49 percent of the students are not familiar with the Swayam e-learning program. From urban areas 60 percent of the students are familiar and 40 percent of the students are not familiar with the Swayam elearning program. 


\begin{tabular}{|cccccccc}
\hline \multicolumn{2}{|c|}{ Table 6 What kind of device do you used for online classes? } & & \\
\hline Devices & Rural & Percentage & Urban & Percentage & Total & Percentage \\
\hline Smartphone & 69 & $88 \%$ & 53 & $85 \%$ & 122 & $87 \%$ \\
\hline Desktop & 9 & $12 \%$ & 9 & $15 \%$ & 18 & $13 \%$ \\
\hline Tablet & 0 & - & 0 & - & 0 & - \\
\hline Laptop & 0 & - & 0 & - & 0 & - \\
\hline Total & 78 & 100 & 62 & 100 & 140 & 100 \\
\hline
\end{tabular}

(Source: Primary data)

It is observed that the majority (88\%) of the students from rural areas are using smartphones for accessing online classes, and 12 percent of the students are using the desktop for accessing online classes. From the urban area, 85 percent of the students are using smartphones, 15 percent of the students are using desktops for accessing online classes.

\begin{tabular}{|c|c|c|c|c|c|c|}
\hline \multicolumn{7}{|c|}{ Table 7 Use of platform for online classes } \\
\hline Platform & Rural & Percentage & Urban & Percentage & Total & Percentage \\
\hline Zoom & 60 & $77 \%$ & 53 & $85 \%$ & 113 & $81 \%$ \\
\hline Google meet & 7 & $9 \%$ & 0 & - & 7 & $5 \%$ \\
\hline WhatsApp & 5 & $6 \%$ & 0 & - & 5 & $4 \%$ \\
\hline You Tube & 4 & $5 \%$ & 5 & $8 \%$ & 9 & $6 \%$ \\
\hline Go To meeting & 2 & $3 \%$ & 4 & $7 \%$ & 6 & $4 \%$ \\
\hline Total & 78 & 100 & 62 & 100 & 140 & 100 \\
\hline
\end{tabular}

Source: Primary data

The above table inferred that the majority (77\%) of the students from rural areas are using Zoom App for attending online classes followed by Google meet 9 percent, Whats App 6 percent, YouTube 5 percent, Go To meeting 3 percent. Of the students from an urban area, 85 percent of the students are using Zoom App for attending online classes followed by YouTube 8 percent, Go To meeting 7 percent.

\begin{tabular}{cccccccc}
\hline \multicolumn{2}{c}{ Table 8 Attending } & online classes on regular basis & & & \\
\hline Classification & Rural & Percentage & Urban & Percentage & Total & Percentage \\
\hline Regularly & 61 & $78 \%$ & 47 & $76 \%$ & 108 & $77 \%$ \\
\hline Occasionally & 11 & $14 \%$ & 15 & $24 \%$ & 26 & $19 \%$ \\
Rarely & 6 & $8 \%$ & 0 & - & 6 & $4 \%$ \\
Total & 78 & 100 & 62 & 100 & 140 & 100 \\
\hline
\end{tabular}

Source: Primary data 
The above table shows that from the rural area, the majority (78\%) of the students are attending online classes on regular basis and the remaining 14 percent of the students are occasionally, 8 percent students are rarely attending online classes, in the same time students from the urban area 76 percent of the students are regularly, 24 percent of the students are occasionally attending online classes.

\begin{tabular}{|c|c|c|c|c|c|c|}
\hline \multicolumn{7}{|c|}{ Table 9 What kind of on-line lectures would you like to attend? } \\
\hline Particulars & Rural & Percentage & Urban & Percentage & Total & Percentage \\
\hline Live stream Lectures & 54 & $69 \%$ & 44 & $71 \%$ & 98 & $70 \%$ \\
\hline $\begin{array}{c}\text { Video Lectures on } \\
\text { YouTube }\end{array}$ & 17 & $22 \%$ & 13 & $21 \%$ & 30 & $21 \%$ \\
\hline $\begin{array}{l}\text { Video Lessons that } \\
\text { Have Been Recorded }\end{array}$ & 5 & $6 \%$ & 5 & $8 \%$ & 10 & $7 \%$ \\
\hline Lessons in Audio & 2 & $3 \%$ & 0 & - & 2 & $2 \%$ \\
\hline Total & 78 & 100 & 62 & 100 & 140 & 100 \\
\hline
\end{tabular}

Source: Primary data

It is observed that from Table 8, the majority (69\%) of the students are interested in live stream lectures from rural areas followed by Video lectures on YouTube 22 percent, Video lessons that have been recorded 6 percent, Lessons in Audio 3 percent. At the same time from urban area majority (71\%) of the students are interested in Live stream lectures followed by Video Lectures on YouTube 21 percent, Video Lessons that have been recorded 8 percent.

\section{RELIABILITY TEST}

The reliability test is managed through SPSS to confirm reliability of data. For this aim, researcher used the Cronbach's Alpha test. If the Alpha value is between, 0.7 to 0.9 , the data is reliable. If the Alpha value falls between, 0.1 to 0.6 , the data is not reliable.

\begin{tabular}{|c|c|}
\hline Table 10 Cronbach's A & \\
\hline \multicolumn{2}{|c|}{ Reliability Statistics } \\
\hline Cronbach's Alpha & $\mathrm{N}$ of Items \\
\hline 0.902 & 11 \\
\hline Source: Sort-out from $\mathrm{p}$ & data (SPSS) \\
\hline
\end{tabular}

The above table depicts that, Cronbach's Alpha value is 0.902 for all 11 items which is falling between, 0.7 to 0.9 . It is specified that the data is highly reliable.

\section{STUDET'S INVOLVEMENT AND COMMITMENT}

the students Involvement and Commitment during Online Classes collected on Five-point Likert Scale, ranging from Strongly Disagree to Strongly Agree in the below Table 11. 


\begin{tabular}{|c|c|c|c|c|c|c|c|c|c|}
\hline S.NO & Statement & $\begin{array}{c}\text { Area of } \\
\text { Residence }\end{array}$ & Measures & $\begin{array}{l}\text { Strongly } \\
\text { Disagree }\end{array}$ & Disagree & Neutral & Agree & $\begin{array}{l}\text { Strongly } \\
\text { Agree }\end{array}$ & Total \\
\hline \multirow[t]{5}{*}{1} & $\begin{array}{l}\text { During online classes, } \\
\text { I asked questions. }\end{array}$ & Rural & Frequency & 0 & 2 & 34 & 30 & 12 & 78 \\
\hline & & & $\%$ & - & 3 & 44 & 38 & 15 & 100 \\
\hline & & Urban & Frequency & 3 & 0 & 19 & 33 & 7 & 62 \\
\hline & & & $\%$ & 5 & - & 31 & 53 & 11 & 100 \\
\hline & & & Total & 3 & 2 & 53 & 63 & 19 & 140 \\
\hline \multirow[t]{5}{*}{2} & $\begin{array}{l}\text { During online classes, } \\
\text { I respond to questions. }\end{array}$ & Rural & Frequency & 4 & 6 & 28 & 34 & 6 & 78 \\
\hline & & & $\%$ & 5 & 8 & 36 & 44 & 7 & 100 \\
\hline & & Urban & Frequency & 0 & 3 & 16 & 39 & 4 & 62 \\
\hline & & & $\%$ & - & 5 & 26 & 63 & 6 & 100 \\
\hline & & & Total & 4 & 9 & 44 & 73 & 10 & 140 \\
\hline \multirow[t]{5}{*}{3} & $\begin{array}{l}\text { During online classes, } \\
\text { I participate in the } \\
\text { activities assigned by } \\
\text { my teacher. }\end{array}$ & Rural & Frequency & 8 & 2 & 13 & 40 & 15 & 78 \\
\hline & & & $\%$ & 10 & 3 & 17 & 51 & 19 & 100 \\
\hline & & Urban & Frequency & 4 & 4 & 12 & 36 & 6 & 62 \\
\hline & & & $\%$ & 6 & 6 & 20 & 58 & 10 & 100 \\
\hline & & & Total & 12 & 6 & 25 & 76 & 21 & 140 \\
\hline \multirow[t]{5}{*}{4} & $\begin{array}{l}\text { During online classes, } \\
\text { I communicate with } \\
\text { my classmates. }\end{array}$ & Rural & Frequency & 2 & 4 & 18 & 42 & 12 & 78 \\
\hline & & & $\%$ & 3 & 5 & 23 & 54 & 15 & 100 \\
\hline & & Urban & Frequency & 3 & 4 & 27 & 22 & 6 & 62 \\
\hline & & & $\%$ & 5 & 6 & 44 & 35 & 10 & 100 \\
\hline & & & Total & 5 & 8 & 45 & 64 & 18 & 140 \\
\hline
\end{tabular}

Source: Primary Data

The above study reveals that the students from the rural area, 38 percent and 15 percent and from urban area 53 percent and 11 percent of the respondents are involved that they agree and strongly agree individually with the statement of during online classes they are asked questions. As far as During online classes respond to question, about 44 percent and 7 percent of the students from the rural area agreed and strongly agreed, while from the area of urban 63 percent and 6 percent expressed that they agree and strongly agree. From rural areas majority of the respondents, 51 percent and 19 percent committed with their participation in the activities assigned by the teacher, while from the area of urban, 58 percent and 10 percent of the respondents agreed and strongly agreed with that statement. About the statement During online classes, they communicate with their classmates, as for 54 percent and 15 percent of the respondents from rural area are, agreed and strongly agreed, from the urban area, 35 percent and 10 percent of the respondents agreed and strongly agreed with the statement.

\section{ANALYSIS OF VARIANCE (ANOVA)}

Hypothesis 1: Ho: There is no statistically difference between Area of Residence and students Commitment during online classes. 


\begin{tabular}{|c|c|c|c|c|c|c|}
\hline \multicolumn{7}{|c|}{ ANOVA RESULTS } \\
\hline Variable & & $\begin{array}{c}\text { Sum of } \\
\text { Squares }\end{array}$ & df & $\begin{array}{c}\text { Mean } \\
\text { Square }\end{array}$ & $\mathbf{F}$ & Sig. \\
\hline \multirow[t]{3}{*}{$\begin{array}{l}\text { 1. During online classes, I } \\
\text { asked questions. }\end{array}$} & $\begin{array}{l}\text { Between } \\
\text { Groups }\end{array}$ & 0.001 & 1 & 0.001 & 0.002 & 0.969 \\
\hline & $\begin{array}{l}\text { Within } \\
\text { Groups }\end{array}$ & 91.22 & 138 & 0.661 & & \\
\hline & Total & 91.221 & 139 & & & \\
\hline \multirow[t]{3}{*}{$\begin{array}{l}\text { 2. During online classes, I } \\
\text { respond to questions. }\end{array}$} & $\begin{array}{l}\text { Between } \\
\text { Groups }\end{array}$ & 3.097 & 1 & 3.097 & 4.564 & 0.034 \\
\hline & $\begin{array}{l}\text { Within } \\
\text { Groups }\end{array}$ & 93.646 & 138 & 0.679 & & \\
\hline & Total & 96.743 & 139 & & & \\
\hline \multirow{3}{*}{$\begin{array}{l}\text { 3. During online classes, I } \\
\text { participate in the activities } \\
\text { assigned by my teacher. }\end{array}$} & $\begin{array}{l}\text { Between } \\
\text { Groups }\end{array}$ & 0.256 & 1 & 0.256 & 0.223 & 0.638 \\
\hline & $\begin{array}{l}\text { Within } \\
\text { Groups }\end{array}$ & 158.43 & 138 & 1.148 & & \\
\hline & Total & 158.686 & 139 & & & \\
\hline \multirow{3}{*}{$\begin{array}{l}\text { 4. During online classes, I } \\
\text { communicate with my } \\
\text { classmates. }\end{array}$} & $\begin{array}{l}\text { Between } \\
\text { Groups }\end{array}$ & 4.39 & 1 & 4.39 & 5.429 & 0.021 \\
\hline & $\begin{array}{l}\text { Within } \\
\text { Groups }\end{array}$ & 111.581 & 138 & 0.809 & & \\
\hline & Total & 115.971 & 139 & & & \\
\hline
\end{tabular}

Source: Calculations on SPSS

The above table reveals that the results of the ANOVA test. It is found that from Table 12, the p-value for about 2nd and 4th statements such as "During online classes, I respond to questions" and "During online classes, I communicate with my classmates", are less than 0.05 at 5 percent level of significance and hence the null hypothesis has been rejected. So, it can be inferred that there is a statistically significant difference between the Area of the residence ad student's involvement during online classes. Oppositely, the above table shows that the p-value for about 1st and 3rd statements just as "During online classes, I asked questions" and "During online classes, I participate in the activities assigned by my teacher.", are more than 0.05 at 5 percent level of significance and so the null hypothesis of these statements have been accepted. Hence, it can be decided that there is no statistically significant difference between the Area of residence and student's commitment during online classes.

\begin{tabular}{|c|c|c|c|c|c|}
\hline \multicolumn{6}{|c|}{ Descriptive Statistics } \\
\hline Statement & $\mathbf{N}$ & Minimum & Maximum & Mean & $\begin{array}{l}\text { Std. } \\
\text { Deviation }\end{array}$ \\
\hline 1. I have excellent Internet access. & 140 & 1 & 5 & 3.3929 & 1.0505 \\
\hline $\begin{array}{l}\text { 2. There are no audio disruptions } \\
\text { during online classes. }\end{array}$ & 140 & 1 & 5 & 3.1143 & 1.01843 \\
\hline $\begin{array}{l}\text { 3. I've had no video issues in online } \\
\text { classes. }\end{array}$ & 140 & 1 & 5 & 3.2429 & 1.14346 \\
\hline
\end{tabular}




\begin{tabular}{|c|c|c|}
\hline $\begin{array}{l}\text { 4. It is goo } \\
\text { duri }\end{array}$ & $\begin{array}{l}\text { each out to content } \\
\text { online class. }\end{array}$ & 14 \\
\hline 5. The instr & $\begin{array}{l}\text { r's technical abilities } \\
\text { excellent. }\end{array}$ & \\
\hline $\begin{array}{r}\text { 6.E-conten } \\
\text { your }\end{array}$ & $\begin{array}{l}\text { aterials provided by } \\
\text { ructor is good }\end{array}$ & 14 \\
\hline & (list wise) & \\
\hline Table 14 Fiv & jint Likerts scale value & \\
\hline RANGE & EXPLANATION & \\
\hline $4.51-5.0$ & STRONGLY AGREE & \\
\hline $3.51-4.50$ & AGREE & \\
\hline $2.51-3.50$ & NEUTRAL & \\
\hline $1.51-2.50$ & DISAGREE & \\
\hline $1.00-1.50$ & STRONGLY DISAGREE & \\
\hline
\end{tabular}

It can be seen from Table 13 that, the mean value of the 5th statement (3.75), 6th statement (3.52) these two statements agreed and accepted by the rural and urban area of the student's satisfaction level towards online classes. At the same time, the rural and urban areas of the students, Neutral about the 1st, 2nd, 3rd, and 4th statements.

\begin{tabular}{|ccccc}
\hline \multicolumn{5}{|c|}{ Table 15 Student's Final Opinion towards e-learning } \\
\hline Particulars & Rural & Percentage & Urban & Percentage \\
\hline Extremely unenjoyable & 4 & $5 \%$ & 6 & $10 \%$ \\
\hline Very unenjoyable & 12 & $15 \%$ & 4 & $6 \%$ \\
\hline Somewhat enjoyable & 16 & $21 \%$ & 16 & $26 \%$ \\
\hline Very enjoyable & 32 & $41 \%$ & 16 & $26 \%$ \\
\hline Extremely enjoyable & 14 & $18 \%$ & 20 & $32 \%$ \\
\hline Total & 78 & 100 & 62 & 100 \\
\hline
\end{tabular}

According to the above table, the majority (41\%) of rural area students and $26 \%$ of urban area students expressed very enjoyment, and approximately $14 \%$ of rural area students and $32 \%$ of urban area students expressed "extremely enjoyable" on the e-learning during the covid-19 situation. However, 20 percent of rural students and 16 percent of urban students report that e-learning is unenjoyable due to technical difficulties.

Hypothesis 2: The following hypothesis is developed and tested using SPSS.

Ho: There is no significant difference between Area of residence and Student's final opinion on e-learning. 


\begin{tabular}{|c|c|c|c|}
\hline \multicolumn{4}{|c|}{$\begin{array}{l}\text { Table } 16 \text { Chi-Square test - Area of residence and final opinion towards e- } \\
\text { learning }\end{array}$} \\
\hline \multicolumn{4}{|c|}{ Chi-Square Tests } \\
\hline Variable & Value & df & $\begin{array}{l}\text { Asymptotic } \\
\text { Significance (2-sided) }\end{array}$ \\
\hline Pearson Chi-Square & $9.082^{\mathrm{a}}$ & 4 & 0.059 \\
\hline Likelihood Ratio & 9.257 & 4 & 0.055 \\
\hline $\begin{array}{l}\text { Linear-by-Linear } \\
\text { Association }\end{array}$ & 0.433 & 1 & 0.511 \\
\hline $\mathrm{N}$ of Valid Cases & 140 & & \\
\hline
\end{tabular}

It is evident that in the Table 16, the Pearson Chi-square value is 9.082 at $4 \mathrm{df}$, and the P-value is greater than 0.05 at a 5 percent level of significance. So, the null hypothesis has been accepted as the p-value is greater than 0.05 . So, it can be hypothesized that there is no significant difference and final opinion towards elearning.

\section{IMPORTANT FINDINGS}

- It has been discovered that the majority (88\%), of students in rural areas, use smartphones to attend online classes, while 85 percent of students in urban areas use smartphones. At the same time, $13 \%$ of students in rural areas and $15 \%$ of students in urban areas use different devices to access online classes.

- It is found that most (77\%), of the rural area's students, and (85\%), of the urban area's students have been used Zoom online platform to manage online classes.

- Surprisingly, the majority (78\%), of students from rural areas and 76 percent of students from urban areas have regularly attended online classes. Approximately (14\%) of students from rural areas and 24\% of students from urban areas have taken online classes on a sporadic basis.

- It is investigated that most (69\%), of the students from a rural area, and 71 percent, of the students from urban have very much interest in Live stream lectures. On the other hand, 22 percent from rural areas, 21 percent from urban areas students have shown interest in video lectures on YouTube rather than Recorded video and audio lessons.

- Due to technical difficulties, it was discovered that the majority of students from rural and urban areas did not respond well during online classes.

- It is interesting to note that approximately 41 percent of students from rural areas and 26 percent of students from urban areas expressed that elearning was very enjoyable, whereas approximately 15 percent of students from rural areas and 6 percent of students from urban areas expressed that e-learning was "very unenjoyable." 


\section{CONCLUSION}

The study defined several types of impacts of the Covid - 19 pandemic and lockdown on the Higher education sector and bound it to e-learning. The study also concentrated on the satisfaction level of degree students on e-learning in Telangana State and analyzed students' Commitment and Involvement towards e-learning. It is inferred that most of the degree students from rural and urban areas have used smartphones to access e-learning. The majority of the students from rural and urban areas are interested in Livestream lectures rather than YouTube lessons and audio, video-recorded lectures. However, classroom lectures are preferred by students over virtual lectures. Virtual lectures are largely passive and solitary, whereas classroom lectures are more engaged and cohesive. During this pandemic, the majority of students from rural and urban areas felt that e-learning enabled them to stay at home and continue their studies. the students are from Rural area background, they unable to attend the online classes due to various reasons such as lack of android phones, insufficient data, poor internet facility, power outages, and technical glitches, etc. Finally, the government of Telangana must and should take the required steps to address the numerous e-learning interruptions, such as the urban-rural gap, Internet access, and power outages, as well as to provide students with devices to make e-learning more successful.

\section{REFERENCES}

Adnan, M., \& Anwar, K. (2020). Online Learning amid the COVID-19 Pandemic: Students' Perspectives. Online Submission, 2(1), 45-51. Retrieved from https://doi.org/10.33902/JPSP.2020261309

Jindal, A., \& Chahal, B. P. S. (2018). Challenges and Opportunities for Online Education in India. Pramana Research Journal, 8(4), 99-106. Retrieved from https://www.pramanaresearch.org/gallery/prj_c_ap_12.pdf

Kantipudia, M. P., Mosesa, C. J., Aluvalub, R., \& Gouda, G. T. (2021). Impact of Covid19 on Indian Higher Education. Library Philosophy and Practice, 1-11. Retrieved from https://www.researchgate.net/profile/Mvv-PrasadKantipudi/publication/349693017_Impact_of_Covid19_on_Indian_Higher_Education/links/60405fe0a6fdcc9c780f7bab/Impac t-of-Covid-19-on-Indian-Higher-Education.pdf

Monika Koul, \& Jyoti Bhola. (2020, 6 May). Assessing the Impact of Lockdown on Undergraduate Teaching: A Survey Based Approach, Digital Learning. Retrieved from https://digitallearning.eletsonline.com/2020/05/assessing-the-impact-oflockdown-onundergraduate-teaching-a-survey-based-approach/

Naciri, A., Baba, M. A., Achbani, A., \& Kharbach, A. (2020). Mobile learning in Higher education: Unavoidable alternative during COVID-19. Aquademia, 4(1), ep20016. Retrieved from https://doi.org/10.29333/aquademia/8227

Nagaraj Subbarao, A., Srinivas, A., \& Bangra, M.K. (2020, May 25). 7 Reasons Why Students Should be Part of Online Classes During Lockdown. BW Education. Retrieved from http://bweducation.businessworld.in/article/7-ReasonsWhy-Students-Should-Be-Part-OfOnline-Classes-During-Lockdown-/2505-2020-193112/

Neelavathy, M. (2020). Impact of Lockdown on Learning Status of College Students During Covid-19 Pandemic in Madurai District. Aut Aut Research Journal, X1 
X, 1, 329-338. Retrieved from http://www.autrj.com/gallery/35-aut-nov2020.pdf

Siddiqui, M. I., Shah, R., \& Ariser, K. N. (2021). Challenges of online learning and attitude of medical student at LUMHS: Comparative study among rural and urban students during covid-19 pandemic. In Medical Forum Monthly (pp. 82-86).

Tari, M. S., \& Amonkar, M. G. (2020). Impact of Covid on higher education in India. Educational Resurgence, 2(5), 22-27. Retrieved from https://coed.dypvp.edu.in/educational-resurgencejournal/documents/jan-2021/22-27.pdf

Vinod Pavarala, \& Vasuki Belavadi. (2020). UOH Conducts Survey, Finds Students Don't Have Access to Net, Electricity. The Indian Express. Retrieved from https://www.edexlive.com/news/2020/apr/23/uoh-conducts-surveyfinds-students-dont-haveaccess-to-net-electricity-drops-idea-of-onlineclas-11524.html

World Bank Group. (2020, April 8,). The COVID-19 Crisis Response: Supporting Tertiary Education for Continuity, Adaptation and Innovation. Retrieved from http://pubdocs.worldbank.org/en/621991586463915490/WBTertiary-Ed-and-Covid-19-Crisisfor-public-use-April-9.pdf 